\title{
intuitio
}

\section{A CRÍTICA ANTIFETICHISTA DE ENRIQUE DUSSEL}

\section{THE ANTIFETISHIST CRITIC OF ENRIQUE DUSSEL}

\author{
Tiago dos Santos Rodrigues'
}

Resumo: Este artigo apresenta a base da crítica antifetichista elaborada por Enrique Dussel. Para Dussel, o anti-intelectualismo por excelência não atende pelo nome de "ideologia", mas de "fetiche". A inversão fetichista é a que transforma o ser humano [sujeito] em coisa e coisas em sujeitos, divinizando o produzido [a obra humana] e relativizando o absoluto [a vida humana]. A crítica a todo sistema político e econômico, se se quer radical, deverá, então, denunciar os aspectos fetichistas de ditos sistemas, isto é, os momentos em que eles se autonomizam e não fazem referência à vida humana na qual se originam e da qual dependem.

Palavras-chave: Antifetichismo. Religião. Exterioridade. Capitalismo

Abstract: This article presents the basis of the antifetishist critique elaborated by Enrique Dussel. For Dussel, the anti-intellectualism par excellence does not go by the name of "ideology", but of "fetish". The fetishist inversion is what transforms the human being, the subject, into things and things into subjects, divining the produced, the human work, and relativizing the absolute, the human life. Criticism of any political and economic system, if one wants to be radical, must then denounce the fetishistic aspects of these systems, that means, the moments in which they become autonomous and do not make reference to the human life in which they originate and of which depend.

Keywords: Antifetishist. Religion. Exteriority. Capitalism.

\footnotetext{
1 Pontifícia Universidade Católica do Rio Grande do Sul (PUCRS). ORCID: http://orcid.org/o0oo0002-8238-4508.E-Mail: tiagorodrigues1492@gmail.com
} 
Ouvi a palavra de lahweh, príncipes de Sodoma, prestai atenção à instrução do nosso Deus, povo de Gomorra! Que me importam os vossos inúmeros sacrifícios?

diz lahweh. Estou farto de holocaustos de carneiros e da gordura de bezerros cevados; no sangue de touros, de cordeiros e de bodes não tenho prazer. Quando vindes à minha presença quem vos pediu que pisásseis os meus átrios? Basta de

trazer-me oferendas vãs: elas são para mim um incenso abominável. Lua nova, sábado e assembleia, não posso suportar iniquidade e solenidade! As vossas luas novas e as vossas festas, a minha alma as detesta: elas são para mim um fardo; estou cansado de carregá-lo. Quando estendeis as vossas mãos, desvio de vós os meus olhos; ainda que multipliqueis a oração não vos ouvirei. As vossas mãos

estão cheias de sangue: lavai-vos, purificai-vos! Tirai da minha vista as vossas más ações! Cessai de praticar o mal, aprendei a fazer o bem! Buscai o direito, corrigi o opressor! Fazei justiça ao órfão, defendei a causa da viúva! Então, sim, poderemos discutir, diz lahweh: Mesmo que os vossos pecados sejam como escarlate, tornar-se-ão alvos como a neve; ainda que sejam vermelhos como carmesim tornar-se-ão como a lã. Se estiverdes dispostos a ouvir, comereis o fruto precioso da terra. Mas se vos recusardes e vos rebelardes, sereis devorados pela espada! Eis o que a boca de lahweh falou. Isaías 1, 10-20.

É preciso que se façam alguns apontamentos prévios ao discurso que será aqui proposto visto que a utilização de certas fontes não estritamente filosóficas possa causar, em um e outro espírito mais purista, um incômodo desnecessário. Falaremos de religião e teologia, mas não falaremos de religião e teologia no sentido lato destes termos e nem faremos religião e teologia. Cabe ao teólogo fazer teologia, porém cabe ao filósofo fazer a crítica à teologia. Mas por que fazer crítica à teologia? Em primeiro lugar, não nos parece que se possa admitir que haja algo que concirna ao humano e que esteja vedado à crítica filosófica, seria admitir à filosofia um limite que ela, no decorrer dos séculos, ignora conhecer; a sua não submissão a nenhum tipo de "dogmatismo" (no sentido pejorativo que conhecemos) e sua autonomia com respeito a qualquer outro conhecimento, atestam 
a própria liberdade ${ }^{2}$ que tem em consciência e que logrou conquistar. A filosofia é indiscreta por sua própria natureza, é aquela que ao ver uma porta busca o buraco da fechadura, e se não há o buraco, faz o buraco. Em segundo lugar, resta-nos, portanto, considerar se a teologia concerne de modo suficientemente importante ao ser humano a fim de que a filosofia se digne [porque sempre teve uma dose de soberba] a operar a sua crítica. Do que fala a teologia? A resposta mais comum dirá: de Deus; a resposta mais cretina: do sexo dos anjos. A última é falsa, a primeira inexata. A teologia trata, de fato, do absoluto, das realidades últimas - assim que toda a teologia, em seus vários momentos, é uma escatologia expandida. Objeção: mas o ser humano, limitado e finito, não tem conhecimento e experiência do absoluto e nem pode tê-los justamente em razão de sua limitação e finitude. Resposta: não pode tê-los, conhecimento e experiência do absoluto, mas postula o absoluto para justificar a sua ação e, em última análise, a sua própria existência, porque, limitado e finito, não pode justificar a sua ação, tampouco sua própria existência, a partir de si próprio. Sendo assim, a teologia não somente concerne de modo suficientemente importante ao ser humano (caso fosse somente um aspecto da sua vida), ela concerne de modo total ao ser humano, pois lida com a totalidade da existência humana. Iremos aprofundar este ponto no decorrer do texto, então, quanto a isso, nos deteremos aqui por enquanto.

Ainda uma última dificuldade pode subsistir, qual seja, a opinião de que textos religiosos e teológicos são deveras obscuros e ininteligíveis. Ora, isso ocorre, cremos, pelo mesmo motivo que, costumeiramente, textos hegelianos e heideggerianos, por exemplo, são igualmente tidos por obscuros e ininteligíveis: pelo desconhecimento desses textos e de seus marcos categoriais. Um texto religioso não é irracional porque não está conformado

\footnotetext{
2 Essa liberdade, para nós, não é, no entanto, arbitrária e tampouco absoluta. A objeção: mas se então não é absoluta, ela encontra limites. Reforçamos: a filosofia não tem limites de crítica, contudo, a sua crítica (para que de fato seja crítica e não apologia ao estatuído) já se encontra orientada, investida de responsabilidade - Cf. "Verdade e justiça”, In. LEVINAS, Emmanuel. Totalidade e infinito. Trad. José Pinto Ribeiro. Lisboa: Edições 70, 2000. p. 68-87.
} 
pelas medidas de expressão filosófica e "científica". A expressão religiosa não é irracional, é outra expressão que não a filosófica ou científica. Um texto religioso (como indica Enrique Dussel) é uma narrativa racional baseada em símbolos. A tarefa filosófica, por conseguinte, é tomar esse texto, pensar o que o símbolo nos tem a ensinar ${ }^{3}$, e descobrir seu sentido último e as categorias latentes (critérios e princípios) que o constituem ${ }^{4}$ - extrair essas categorias e esses critérios é que é do interesse da filosofia, para que os agregue na sua "caixa de ferramentas" crítica. De outra parte, isso não é em nada estranho à filosofia. Os mitos gregos que os filósofos e filósofas não cansam de comentar há mais de vinte séculos são em boa parte, se não em sua maioria, narrativas religiosas gregas, ocorre que de uma religião já por ninguém professada hoje. A objeção: mas a filosofia nasceu com esses mitos, logo, eles são como que "mais" filosóficos, pois moldaram a filosofia, do que propriamente religiosos. A resposta: não se deve, nos alerta Dussel, confundir o "conteúdo de eticidade de uma cultura com a formalidade propriamente filosófica"s. Caso se queira insistir nessa identidade, da eticidade grega com a formalidade filosófica, haverá de se admitir, com Eboussi Boulaga, que "a filosofia é um dos símbolos e instituições que o Ocidente transportou para fora de si e a ofereceu como maneira de assimilar os outros"6 - assimilação desde o oferecimento (e, academicamente, pela imposição) da eticidade grega (um conteúdo particular) como sendo a racionalidade "universal". Nós, pelo contrário, não tomaremos parte nesta universalização ideológica da particularidade

\footnotetext{
3 Pois pensar é ser ensinado - Cf. LEVINAS, Emmanuel. Totalidade e infinito. Trad. José Pinto Ribeiro. Lisboa: Edições 70, 2000. p. 182].

4 Cf. DUSSEL, Enrique. Pablo de Tarso en la filosofia politica actual. Ciudad de México: San Pablo, 2012. p. 9-14.

5 DUSSEL, Enrique. Ética da libertação na idade da globalização e da exclusão. Trad. Ephraim Ferreira Alves, Jaime A. Classen, Lúcia M. E. Orth. Petrópolis: Editora Vozes, 2000. p. 19.

6 BOULAGA, Eboussi. La crise du Muntu. Authenticité africaine et phiiosophie. Paris: Presence Africaine, 1977. p. 120. Apud. DUSSEL, Enrique. Ética da libertação na idade da globalização e da exclusão. Trad. Ephraim Ferreira Alves, Jaime A. Classen, Lúcia M. E. Orth. Petrópolis: Editora Vozes, 2000. p. 76.
} 
que assume as faces do helenocentrismo, ocidentalismo e eurocentrismo. Saberemos ter ouvidos e nos pôr à escuta de uma sabedoria tão antiga quanta a grega, e, pensamos, mais radicalmente crítica que ela.

[...] die Seele, der Messias, die Apokalypse sind das Apriori aller Politik und Kultur ${ }^{8}$

Ernst Bloch.

“Quando o homem chega no limite encontra pela frente o 'além'; quando a finitude se descobre como tal, pode propor-se a questão do infinito; quando o tempo entra em crise, nasce a possibilidade de se abrir para a eternidade" ${ }^{\prime \prime}$. São os casos-limites existenciais que fundam a questão arqueológica, o logos (discurso/razão) sobre a origem. E falar de origem é igualmente falar do fim, pois é a origem que dá os condicionamentos do (possível ou não) fim. Assim que Enrique Dussel dará atenção à arqueológica simbólica dos povos, ou seja, aos seus relatos de origem, e, em especial, aos dos povos da Ameríndia. "Nada era profano [na Ameríndia]; tudo na vida imitava aos atos arquetipais dos deuses. O símbolo religioso era o símbolo por excelência, era o único símbolo"10. Sagrado era o ciclo agrícola, a revolução dos astros.

\footnotetext{
7 Para a crítica que Dussel faz aos "centrismos" ideológicos da história da filosofia: Cf. "História mundial das eticidades" [Introdução]. In. DUSSEL, Enrique. Ética da libertação na idade da globalização e da exclusão. Trad. Ephraim Ferreira Alves, Jaime A. Classen, Lúcia M. E. Orth. Petrópolis: Editora Vozes, 2000. p. 19-88; DUSSEL, Enrique. Política da libertação: história mundial e crítica, v.1. Trad. Paulo César Carbonari (org.). Passo Fundo: Editora IFIBE, 2014.

8 "[...] a alma, o messias, o apocalipse são os a priori de toda a política e cultura." BLOCH, Ernst. Geist der utopie. Munchen und Leipzig Ver, Lag von Dunker \& Humblot, 1918. p. 433.

9 DUSSEL, Enrique. Para uma ética da libertação latino-americana V: uma filosofia da religião antifetichista. Trad. Luiz João Gaio. São Paulo: Edições Loyola, Editora UNIMEP, s/a. p. 9.

10 DUSSEL, Enrique. Para uma ética da libertação latino-americana V: uma filosofia da religião antifetichista. Trad. Luiz João Gaio. São Paulo: Edições Loyola, Editora UNIMEP, s/a. p. 11.
} 
O sagrado era a norma para a totalidade da vida, a tal ponto que o imprevisível, o que pudesse dar lugar ao profano ou monstruoso ("fora da ordem") era igualmente sacralizado". Assim, por exemplo, os doentes e as crianças deformadas ou nascidas antes do tempo - ao contrário dos espartanos, mas pelas mesmas razões - eram declarados divinos, protegidos de maneira especial' ${ }^{12}$.

Tudo estava cheio dos deuses, tudo ganhava sentido e, consequentemente, uma justificação já que, pela presença divina, o acaso e sem razão era excluído das possibilidades. O acaso e sem razão, por exemplo, de uma provável enchente em uma área normalmente seca no século XV no reino dos chimús, que hoje compreende boa parte do território peruano, e que deve ter Ihes trazido danos ao seu sistema de irrigação. Os chimús, naturalmente, entenderam aquilo, no mínimo, como uma espécie de aviso. Em razão disso, para abrandar a ira da sua divindade e pedir-lhe ajuda, o reino Chimú realizou aquilo que até o momento é o maior sacrifício de crianças da história mundial: foram 140 crianças entre 5 e 14 anos de idade juntamente com outras 200 lhamas $^{13}$. O interessante para nós é: como pode ter havido o sacrifício de 140 crianças - inocentes em todos os sentidos - e isso não ter causado uma revolta? Como suas mães, pais, irmãos, amigos as viram serem retiradas do seu convívio e irem para a morte certa? Pelo mesmo motivo acima aludido; porque estes sacrifícios eram justamente isso: sacrifícios, ou seja, essas mortes estavam carregadas de sentido e não foram inscritas no reino do absurdo ${ }^{14}$, de outra parte,

\footnotetext{
"Aqui Dussel se refere particularmente aos povos que habitavam a região hoje compreendida pelo México.

12 DUSSEL, Enrique. Para uma ética da libertação latino-americana V: uma filosofia da religião antifetichista. Trad. Luiz João Gaio. São Paulo: Edições Loyola, Editora UNIMEP, s/a. p. 14.

13 ROMEY, Kristin. "Ancient Mass Child Sacrifice May Be World's Largest”. In: https://news. nationalgeographic.com/2018/04/mass-child-human-animal-sacrifice-peru-chimu-science/. Acesso em: 27/05/2019, 19h.

14 Por essa razão a comunidade judaica prefere o termo Shoá a Holocausto para se referir ao extermínio perpetrado pelos nazistas.
} 
impossível para eles. E eis que um paradoxo se apresenta: lá onde tudo faz sentido é que o absurdo dá as caras e é acolhido de portas abertas em casa $^{15}$. Não sabemos se a ira dos deuses fora abrandada ou se vieram em seu socorro, sabemos, sim, que poucas décadas depois os chimús foram conquistados pelos incas, e estes, cinquenta anos depois, pelos espanhóis.

III

Como dissemos mais acima, de uma ou de outra forma, o ser humano (de modo pessoal ou comunitariamente) postula o absoluto, postula uma realidade última desde onde se justifica e desde onde interpreta sua realidade (em termos de foro íntimo, a realidade desse absoluto pode ser, de fato, crida, ou então ficcionada num "como se" - e não nos importará aqui se se dá num ou noutro modo, a questão importante para nós é que ela se dá). A consideração do absoluto pode, por sua vez, se dar basicamente de duas maneiras - essas de importância para nós: seja como i) totalidade total do mundo, seja como ii) exterioridade radical ao mundo. A primeira resultará numa religião ontológica, fetichista. A segunda resultará em uma religião meta-física, antifetichista. Dussel analisará a primeira especialmente na experiência europeia e na sua formulação hegeliana - a qual passaremos agora. Ao problema colocado por Friedrich Heinrich Jacobi, de que ou Deus era um ser subsistente fora do eu, ou o eu era o próprio Deus, Hegel proporá uma terceira alternativa (entre as duas), a de que Deus seja a identidade entre ser e pensar. A religião, por conta disso, será a efetivação dessa identificação perdida na cisão do real do ser. De fato, a Lógica de Hegel inicia-se pelo Ser; o real (o ser) se cinde como cosmologia, iniciando a filosofia da natureza, a partir da natureza aparece a vida e deste surge a vida humana. A vida humana, sendo assim, é a uma determinação do ser que se alienou de si mesmo. "Todo o resta da Lógica é uma involução reflexiva para o ser, mas como resultado; ou seja, é um des-determinar o determinado, [o]

15 Veremos adiante que há como que um paradoxo inverso a este. 
qualificado"16 ${ }^{\prime \prime}$ O ente, a determinação do ser, é o diferido e fundado, possui, à partida, referência à totalidade donde procede e é relativo na totalidade com relação a outros entes - formando todos um mesmo mundo.

Como vemos, a religião seria o momento em que o homem, o ente finito, "pensante, se orienta para o eterno", o momento em que Deus se reúne consigo mesmo no homem "no momento que consiste em negar sua determinação natural imediata e seu querer próprio (...) para estar ensimesmado na dor da negatividade, de sorte que se conheça unido à sua essência (als vereint mit dem Wesen sich zu erkenmen)"17.

No culto perfeito dessa religião não haverá, portanto, distância entre aquele que oferece culto e a quem o culto é oferecido, tanto um como o outro são o mesmo: o sujeito. O culto aqui é culto ao mesmo, é culto a si próprio. De outra parte, Hegel, como sabido, une a história dos povos com a história da religião; assim como o ser é um, e é a totalidade do real, a história é uma só em todas as suas determinações.

A história dos Estados, grau orgânico e real da eticidade (Sittlichkeit) ou "costumes" de um povo, é visualizada a partir da beleza sensível na história da estética, e a partir da autoconsciência clara na história da filosofia, e a partir do seu fundamento na historia da religião. Mas é uma e mesma história. Todas elas culminam, como em seu resultado, no Estado germânico imperial: Inglaterra, Alemanha, e austro-húngaro. Assim sendo, a América Latina não entra em nenhuma das histórias: nem na dos Estados (embora tenha havido dois impérios históricos), nem na da arte, da religião ou da filosofia

\footnotetext{
16 DUSSEL, Enrique. Para uma ética da libertação latino-americana V: uma filosofia da religião antifetichista. Trad. Luiz João Gaio. São Paulo: Edições Loyola, Editora UNIMEP, s/a. p. 72.

17 DUSSEL, Enrique. Para uma ética da libertação latino-americana V: uma filosofia da religião antifetichista. Trad. Luiz João Gaio. São Paulo: Edições Loyola; Editora UNIMEP: Piracicaba, s/a. p. 37.
} 
(embora nos três níveis tivessem insignes manifestações). A divisão ideológica da história (do Oriente para o Ocidente e só no continente euro-asiático) permite consagrar a Europa como a portadora de Deus na história do mundo ${ }^{18}$.

Diante da Europa e de seus Estados, de seus impérios, nenhum outro Estado terá direitos - como exigir direitos (apresentar queixas) perante aqueles que representam a Deus e portam o seu espírito? Se o ser é o divino e a Europa carrega a realização do ser, a Europa é divina e divino é seu cidadão no fato mesmo de ser o que é. O que ocorre na Modernidade, e encontra seu cume com Hegel, é, como vimos, a interiorização do culto e consequentemente a sua "espiritualização". O próprio Hegel elabora a história da religião como a história dessa interiorização, iniciando pela religião natural, passando pela religião da individualidade espiritual, chegando na religião absoluta [o cristianismo que realiza a unidade do Espírito na história pela unidade da Igreja com o Estado ${ }^{19}$.

Haverá alternativas "ateias" a esse modelo. Essas alternativas se designarão ateias por negarem a priori a existência de Deus. Então teremos, por exemplo, o ateísmo holbachiano que propugnava que a única realidade era a natureza e que nada existia fora dela, e, apoiando-se no saber dos filósofos gregos antigos, reconhecia a eternidade do mundo, afirmando enfaticamente que "nada se faz do nada" ${ }^{20}$. E igualmente caminhando nessa

\footnotetext{
18 DUSSEL, Enrique. Para uma ética da libertação latino-americana V: uma filosofia da religião antifetichista. Trad. Luiz João Gaio. São Paulo: Edições Loyola; Editora UNIMEP: Piracicaba, s/a. p. 39.

19 Quanto a isso, Dussel tem tese justamente oposta. O cristianismo, nos diz Dussel, foi o responsável pela dissociação entre religião (igreja) e Estado uma vez que retirou do Estado o seu fundamento teológico ao não reconhecer no Estado qualquer autoridade religiosa, mas, sim, na comunidade religiosa estrita, a Igreja (e sua hierarquia). Não possuindo mais fundamentação religiosa, pois a esfera religiosa havia se deslocado a uma instituição particular, autônoma, e fortemente organizada, o Estado entrou num longo processo de secularização, isto é, de buscar fundamentar-se sem a necessidade de recorrer à autoridade religiosa - processo que não desconheceu, da parte do cristianismo, contradições ao sacralizar monarquias nas cristandades. Cf. DUSSEL, Enrique. Política da Libertação: história mundial e crítica, v.1. Trad. Paulo César Carbonari (coord.). Passo Fundo: Editora IFIBE, 2014. p. 90.

20 Cf. DUSSEL, Enrique. Para uma ética da libertação latino-americana V: uma filosofia da religião antifetichista. Trad. Luiz João Gaio. São Paulo: Edições Loyola; Editora UNIMEP: Piracicaba, s/a. p. 46.
} 
direção, ainda que com pretensões revolucionárias, está Friedrich Engels que sustentará o seguinte: "Temos a certeza (Gewissheit) de que a matéria permanecerá eternamente (ewig) a mesma através de todas as mutações (...) e pela mesma férrea necessidade com que um dia desaparecerá da face da Terra sua floração mais alta, o espírito pensante, voltará a brotar em outro lugar e em outro tempo"21. Tanto o Barão de Holbach quanto Engels, na pretensão de elaborarem filosofias ateias, o que logram fazer são filosofias panteístas e tão carentes da objetividade materialista que desejariam ter quanto o é, por exemplo, o idealismo alemão. Pois, para afirmarem o que afirmam, lançam mão de teses tão "metafísicas" quanto nenhuma outra como é o caso da atribuição de eternidade ao mundo e à natureza. E ambos utilizam da mesma lógica hegeliana, qual seja, a de partir da unidade do ser (natureza/matéria) e dela derivar as realidades determinadas, isto é, os entes permanecem diferenciações da Identidade original, os entes permanecem presos à causalidade da natureza. Não é difícil perceber que o ateísmo aqui é ilusório. O deus que eles pretensamente negam só mudou de nome, agora é a matéria, é a natureza, uma vez que atribuíram a elas uma condição eminentemente divina: a eternidade.

Os três casos que trouxemos [Hegel, Holbach, Engels] são o que Enrique Dussel denomina de religiões fetichistas. O fetiche é o feito pelas mãos humanas, é o produzido pelo ser humano, mas que tem ocultado o seu caráter de produto e se apresenta como autônomo ao humano - é tido como divindade.

Mas esta divindade contemplada não é somente uma verdade teórica, mas é uma "verdade para a ação", não é somente uma ideia, mas uma ideologia. É um "deus" a qual se presta culto, e a quem se oferecem sacrifícios da natureza mas "também sacrifícios humanos" (...). O fetiche é a sacralização do objeto que é mediação necessária para o comprimento

21 ENGELS, Friedrich. Dialektik der Natur, Dietz, Berlin, 1971, p28. Apud. DUSSEL, Enrique. Para uma ética da libertação latino-americana V: uma filosofia da religião antifetichista. Trad. Luiz João Gaio. São Paulo: Edições Loyola; Editora UNIMEP: Piracicaba, s/a. p. 46. 
prático do sistema de dominação: o fetiche erótico é o "falo", o fetiche pedagógico é a "cultura aristocrática", o fetiche econômico-político é o "dinheiro"22.

De perecível o objeto torna-se eterno, de contingente, torna-se necessário, de limitado, torna-se infinito, de criatura, torna-se deus. Para os gregos era a fysis, para os modernos, especialmente Hegel, é a subjetividade europeia, para Holbach, a natureza, para Engels, a matéria. Em todos os casos o absoluto se identificará com o ser e será a totalidade do real que se apresenta no dado. Em todos os casos se justificará a violência que dessas considerações forem produzidas como necessárias. Em todos os casos a crítica à violência e à injustiça estará abortada de partida porque significará a interrupção da ordem natural e necessárias das coisas (contestação de uma ordem divina), pois, a "história" é teodiceia, justificação de deus na história, e deus (o princípio absoluto) só poderá estar justificado (como é a opinião do próprio Hegel) se os acontecimentos de todos os dias não só tiverem lugar em Deus, mas forem obra dele mesmo ${ }^{23}$.

\section{IV}

Pois bem, agora vós, ricos, chorai e gemei por causa das desgraças que estão para vos sobrevir. A vossa riqueza apodreceu e as vossas vestes estão carcomidas pelas traças. O vosso ouro e a vossa prata estão enferrujados e a sua ferrugem testemunhará contra vós e devorará as vossas carnes. Entesourastes como que um fogo nos tempos do fim! Lembrai-vos de que o salário, do qual privastes os trabalhadores que ceifaram os vossos campos, clama, e os gritos dos ceifeiros chegaram aos ouvidos do Senhor dos exércitos. Vivestes faustosamente na terra e vos regalastes; vós vos saciastes no dia da matança. Condenastes o justo e o pusestes à morte: ele não vos resiste. Carta de São Tiago 5, 1-6.

\footnotetext{
22 DUSSEL, Enrique. Para uma ética da libertação latino-americana V: uma filosofia da religião antifetichista. Trad. Luiz João Gaio. São Paulo: Edições Loyola; Editora UNIMEP: Piracicaba, s/a. p. 48 ${ }_{23}$ Cf. DUSSEL, Enrique. Para uma ética da libertação latino-americana V: uma filosofia da religião antifetichista. Trad. Luiz João Gaio. São Paulo: Edições Loyola; Editora UNIMEP: Piracicaba, s/a. p. 39.
} 
É preciso, afirma Dussel, ser ateu de um tal deus - que é deus fetiche. Karl Marx havia entendido a estreita ligação entre a religião e a política, e por isso pode enunciar que o pressuposto de toda a crítica é a crítica à religião; Dussel agrega: crítica à religião fetichista. Há que e negar o deus fetiche. O primeiro passo para a crítica à religião fetichista é negar o pressuposto de todos os supostos da religião fetichista, negar o absolutismo da totalidade, uma vez que a totalidade se afirma como o único real, o todo sem mais. Para além da totalidade é preciso afirmar a exterioridade, o além da totalidade, além do sistema, afirmar o Outro absolutamente outro - que é nada no sistema da totalidade. Se a totalidade não é mais absoluta, como ela pode ser? A totalidade não é mais subsistente em si mesma, mas criada. Hegel, é certo, usou o termo "criação" para se referir à constituição do mundo, do universo, mas a usou sem a devida precisão terminológica. Porque para Hegel o mundo não é criação de Deus, mas é movimento necessário de sua própria lógica. A criação, por definição, é desde o nada (ex nihilo) - é ato sem necessidade alguma, ato livre. Kierkegaard bem notou isso ao acusar a religião hegeliana e ao cristianismo de sua época como religiões pagãs, e por isso deu-lhes o nome de cristandade. A crença na criação desde o nada é a condição de possibilidade para toda a transformação possível. Enquanto os irmãos macabeus eram mutilados e assados vivos, a mãe deles anima a um e o conforta dizendo:

Não sei como é que viestes a aparecer no meu seio, nem fui eu que vos dei o espírito e a vida, nem também fui eu que dispus organicamente os elementos de cada um de vós. Por conseguinte, é o Criador do mundo que formou o homem em seu nascimento e deu origem a todas as coisas, quem vos retribuirá, na sua misericórdia, o espírito e a vida, uma vez que agora fazeis pouco caso de vós mesmos, por amor às suas leis. (...). Filho, tem compaixão de mim, que por nove meses te trouxe em meu seio e por três anos te amamentei, alimentei-te e te eduquei até esta idade, provendo sempre 
ao teu sustento. Eu te suplico, meu filho, contempla o céu e a terra e observa tudo o que neles existe. Reconhece que não foi de coisas existentes que Deus os fez, e que também o gênero humano surgiu da mesma forma. Não temas este carrasco ${ }^{24}$.

A crença no criacionismo - no Deus criador - possibilitou que os irmãos macabeus resistissem à ocupação helênica então dominante, pois sabiam que o Deus que desde o nada os fez, desde o nada os podia libertar, ainda que a totalidade da dominação testemunhasse o contrário ${ }^{25}$. Pierre-Joseph Proudhon mesmo reconhece: “(...) estudando no silêncio de meu coração, e longe de toda a consideração humana, o mistério das revoluções sociais, Deus, o grande Desconhecido [e criador] tornou-se uma hipótese para mim, quer dizer, um instrumento dialético necessário”26.

\footnotetext{
242 Macabeus 7, 22-23; 27-29.

25 Falávamos anteriormente do absurdo que é acolhido na totalidade de sentido. Chegou a hora de darmos o contraponto prometido. Uma das consequências práticas do criacionismo, da tese de que o mundo é criação e não se identifica com o divino [não sendo, portanto, uma determinação sua], é que este mundo se dá, isto é, corre, sem Deus. Há uma distância - infinita - entre o criador e a criação. Ao mesmo tempo que a criação é fruto da ação divina (o criador teve que obrar nela), enquanto propriamente criação (não sendo o criador) o mundo é ausência de Deus. Por isso o criacionismo é a possibilidade de haver o mal (no sentido forte do termo) no mundo, uma vez que possibilita que se considere a não ação e presença de Deus no mundo devido à distância entre um e outro. A criação é criação do hiato do mal, do absurdo, do sem sentido. Um outro texto da tradição criacionista nos indica isso. O livro de Jó nos conta da história de Jó, "servo bom e fiel a Deus", que de uma hora para outra é afligido por uma enormidade de desgraças - os filhos morrem, a riqueza é perdida, a doença se lhe achega. $\mathrm{Na}$ miséria e na doença, ele é tentado por três amigos a admitir que o advento de tais desgraças sobre si sejam decorrentes de alguma falta dele cometida contra Deus; como Elifaz, que the diz: "Eis minha experiência: aqueles que cultivam a iniquidade e semeiam a miséria são também os que as colhem". Jó, no entanto, se recusa a acreditar em tal hipótese. Lemos ao final do livro: "Então lahweh respondeu a Jó, do seio da tempestade, e disse: Quem é esse que obscurece meus desígnios com palavras sem sentido? Cinge-te os rins, como um herói, vou interrogar-te e tu me responderás. Onde estavas quando lancei os fundamentos da terra? Dize-me, se é que sabes tanto. Quem Ihe fixou as dimensões? - se o sabes -, ou quem estendeu sobre ela a régua? Onde se encaixam suas bases, ou quem assentou sua pedra angular, entre as aclamações dos astros da manhã e o aplauso de todos os filhos de Deus?" (Jó, 38, 1-7). Por Jó ter se recusado a admitir que o mal tivesse proveniência divina - e que, portanto, tivesse justificação divina - Deus the recompensa devolvendo em dobro o que havia perdido.
}

26 PROUDHON, Pierre-Joseph. Sistema das contradições econômicas, ou, Filosofia da miséria, tomo I. Trad. J. C. Morel. São Paulo: Ícone, 2003. p. 38. 
Se então a totalidade é criada, ela é cosmos - ordenamento posto. Façamos um esclarecimento terminológico. Para Dussel, cosmos é a totalidade das coisas reais físicas, um exemplo extremo: um planeta qualquer em uma galáxia desconhecida. Mundo é a totalidade dos entes, ou seja, das coisas (do cosmos) inseridas num horizonte de sentido. Deste modo, os entes fazem parte do mundo, não tendo por referência o cosmos, mas a vida humana que lhes conferiu sentindo no seu mundo. "Para modificar o sistema é necessário visualizá-lo como 'possível' (quando ainda não era) e como 'contingente' (quando agora é, mas pode não ser) e por isso pode deixar de ser mediante a práxis revolucionária"27. O cosmos passa a ganhar aqui um estatuto ético. Pois se o cosmos é criação - e não desenvolvimento necessário da lógica do ser e, portanto, causalidade -, então ele é fecundidade, é doação, é oferecimento e gratuidade, porque fruto de um ato de gratuita liberdade incondicionada do Outro absolutamente absoluto.

(...) a práxis libertadora origina um novo discurso teórico que dá fluidez ao uso dos entes desde a possibilidade de mudança do pro-jeto do sistema. A des-cristalização dos usos dos entes leva a descobrir a coisa como a constituição real de algo que pode ser usado de diversas maneiras em diversos sistemas. Mais radicalmente ainda, porém, os entes-coisas são interpretados como o que se pode oferecer ao oprimido (o pão) que se deve libertar. O próprio processo de libertação descobre então os entes-coisas como instrumentos com novos usos e como aquilo que serve-para o Outro. As coisas não são em-si, mas para-o-Outro ${ }^{28}$.

\footnotetext{
27 DUSSEL, Enrique. Para uma ética da libertação latino-americana V: uma filosofia da religião antifetichista. Trad. Luiz João Gaio. São Paulo: Edições Loyola; Editora UNIMEP: Piracicaba, s/a.p. 75.

28 DUSSEL, Enrique. Para uma ética da libertação latino-americana V: uma filosofia da religião antifetichista. Trad. Luiz João Gaio. São Paulo: Edições Loyola; Editora UNIMEP: Piracicaba, s/a. p. 76.
} 
Entramos assim no âmbito cultural e econômico da religião meta-física (não ontológica), religião antifetichista. Pois é nesse oferecimento dos entes ao pobre que acontece o culto. A pergunta seria: como prestar culto (que sempre é um oferecimento) ao Outro absolutamente absoluto se ele de nada tem necessidade, se a ele nada lhe é útil? Presta-se culto ao Outro absolutamente absoluto (Outro arqueológico porque origem de todas as coisas, fundo sem fundo do real) no outro antropológico, naquele que é nada do sistema, nada na totalidade: no pobre e excluído. Se o culto perfeito na religião da ontologia é saber absoluto, o culto "perfeito" na religião meta-física é oferecimento dos objetos da cultura ao pobre, mas importante que se diga, culto "perfeito", entre aspas, porque nunca adequado. "É porque ao Outro infinito ninguém pode prestar um culto adequado (seria necessário estar fora da história e ser divino) que [o Outro infinito] se transforma na medida e possibilidade de toda a justiça histórica"29. Por isso, na perspectiva da religião meta-física, a cultura toda é um ato cultual. Tudo o que se produz ou faz é (em maior ou menor medida) um ato religioso, nada é neutro ou isento. A política e a economia são cultos, ou cultos ao deus fetiche, como já vimos, ou culto ao Deus alterativo ${ }^{30}$. Ou então a economia exigirá sacrifícios humanos - como o capital o exige nas suas dívidas impagáveis e jamais perdoadas -, ou promoverá a produção, reprodução e desenvolvimento da vida de todo o ser humano.

29 DUSSEL, Enrique. Para uma ética da libertação latino-americana V: uma filosofia da religião antifetichista. Trad. Luiz João Gaio. São Paulo: Edições Loyola; Editora UNIMEP: Piracicaba, s/a. p. 91.

30 Tenhamos presente o que Dussel diz em obra mais recente: "La primera relación analógica práctico-productiva, cuasi económica, en su límite y como una experiencia utópica originaria, es la que se establece entre la madre y la prole en el acto mismo de dar de mamar el alimento al recién nacido. La leche de la madre, ese bien consumible, que es una secreción de las glándulas mamarias como en todos los mamíferos, es como un producto metafórico $(P)$ de la propia corporalidad materna, que dona gratuitamente a su prole, con amor desinteresado y sin retorno, al nuevo Otro que ha procreado con exterioridad o autonomía, estableciendo una analógica relación práctico-productiva, es decir, cuasi económica. Es como la económica arqueológica y escatológica, primera e imagen de la última." DUSSEL, Enrique. 16 tesis de economia política: interpretación filosófica. México: Siglo XXI Editores, 2014. p. 35 [§3.4]. 
A única possibilidade econômico-política de prestar culto ao Outro absolutamente absoluto, seria permitir que o fruto do trabalho, objetivado no pro-duto do trabalho, fosse vivido e apropriado pelo trabalhador. Nesta reconciliação do trabalhador com o valor produzido na matéria, seria já não prostituição, mas a satisfação na justiça, o respeito pela Alteridade na política. O "verdadeiro materialismo" consistiria assim em que a matéria da economia não é o homem, mas a natureza ${ }^{31}$. No capitalismo o benefício das empresas se consegue por plusvalia que se extrai do trabalhador metropolitano e da periferia neocolonial. A matéria explorada é o próprio homem, o trabalhador. $O$ que se imola no culto ao fetiche é o trabalhador. No "verdadeiro materialismo", a matéria da economia é a natureza, os entes que nos cercam no mundo: a terra, os instrumentos, os objetos "naturais" (que são sempre definidos a partidos dos objetos "culturais"). O que se coloca ao serviço do Outro é a matéria-trabalhada, o pro-duto: é o culto, não já fetiche, mas ao outro absolutamente absoluto ${ }^{32}$.

\section{V}

A partir do já exposto, gostaríamos de considerar uma famosa tese de Walter Benjamin. Em seu texto, O capitalismo como religião ${ }^{33}$, Benjamin sustenta, em oposição parcial a Max Weber, que o capitalismo não somente tem proximidade com a religião (na análise weberiana, com o cristianismo calvinista), mas é ele próprio, o capitalismo, uma religião. Ora, vimos - a partir de Dussel - que Benjamin está correto ao afirmar isso, o que queremos

\footnotetext{
31 Natureza é o cosmos incorporado num horizonte de sentido, é a totalidade dos entes num horizonte de sentido.

32 DUSSEL, Enrique. Para uma ética da libertação latino-americana V: uma filosofia da religião antifetichista. Trad. Luiz João Gaio. São Paulo: Edições Loyola; Editora UNIMEP: Piracicaba, s/a. p. 99. 33 Cf. BENJAMIN, Walter. O capitalismo como religião. Trad. Nélio Schneider. São Paulo: Boitempo, 2013.
} 
enfatizar (pois cremos já termos dito) é que dizer que o capitalismo seja uma religião - embora verdade - é, em certo sentido, uma banalidade, pois todo o sistema econômico possível é uma religião. Dizer que o capitalismo é uma religião ainda não é crítica suficiente; criticar isso é como criticar água envenenada por ser molhada. A crítica a ser feita é o fato de que o capitalismo é a maior religião fetichista da história. Não é, portanto, o caráter religioso do capitalismo que deve ser o alvo da crítica (seu caráter cultual), mas o seu caráter fetichista, o fato de que se apresenta como a única alternativa possível de sistema econômico (ou seja, como necessário e eterno, como entidade divina e não como - que é o real - sistema criado, produzido, contingente).

Desde as leituras da obra de Marx que empreendeu nos anos 1980, Enrique Dussel tem feito a crítica ao capitalismo nesse registro - como sistema [religião] fetichista. Acompanhemos essa citação de Dussel em obra mais recente.

En la relación dialéctica de "( $\mathrm{A})$ trabajo vivo" con "(B) valor" puede igualmente negarse el trabajo vivo del trabajador como la fuente creadora del valor (su creador, y esencia del capital), y con ello el valor aparece como originándose a sí mismo, como capital, y en este caso el capital pretende crear valor desde sí, de la nada (de trabajo). Se trataría de la fetichización del valor, es decir, del capital como totalidad. Siendo "hecho por las manos del ser humano" se transforma "en un dios al que se le rinde culto" (como indica el poema semita del Salmo 115 , muy conocido y citado por Marx). El trabajador, que es el creador, se transforma en un medio para la ganancia del capitalista; y el capital que es una creación del trabajador, se transforma en el sujeto y el fin del trabajador. Es la inversión por la que "la persona se hace cosa, y la cosa se hace persona", como enuncia Marx (si aplicáramos el enunciado ético de Kant, de nunca tomar a la persona como medio sino como fin, los economistas burgueses y neoliberales resultarían ser crasa- 
mente inmorales y materialistas, ya que para ellos los únicos criterios son el mercado y la competencia: meras cosas) ${ }^{34}$.

O fetichismo capitalista reside então por tomar o criado [o valor objetivado, o capital] como criador desde si, e a tomar o criador [o trabalho vivo: a corporeidade vivente do trabalhador] como mero componente do processo de produção, como mero ente, como uma determinação a mais na totalidade do capital. É a inversão da relação: o fundante se torna fundado e o fundado, fundante. O que o capitalista não vê, e o trabalhador subsumido no processo de produção capitalista também não, é que todo o valor é criação do trabalho vivo na forma de mais-valor, isto é, como trabalho não pago ao trabalhador - é roubo. Desde o ponto de vista puramente econômico, ponto de vista burguês ${ }^{35}$, é o capital que se autoproduz e se autovaloriza, não havendo qualquer relação para com o trabalho humano, com a vida humana. É como se a vida humana, o trabalhador, fosse mera peça de engrenagem que mais hora menos hora poderia ser completamente substituída - o que para a própria lógica do capital é impossível, pois necessita absolutamente da exploração do trabalho. Vejamos, por exemplo, Thomas Piketty, que, mesmo sendo um liberal "moderado" ${ }^{36}$, não consegue deixar de ter uma visão fetichista do capitalismo. Em artigo conjunto, Rosa Maria Marques e Marcel Guedes Leite compilam algumas críticas ao livro do economista francês, " $\mathrm{O} c a$ pital no século XXI". Uma delas, de François Chesnais, diz respeito a que Piketty, a julgar pelo modo como lida com a inferência de dados tanto prospectivamente quanto retrospectivamente, considera o capitalismo como um sistema econômico eterno e insuperável - nos diz Chesnais:

34 DUSSEL, Enrique. 16 tesis de economia política: interpretación filosófica. México: Siglo XXI, 2014. p. 115 [\$7.14].

35 Cf. MARX, Karl. El capital, tomo III. Trad. León Mames. México: Siglo XXI, 1976. p. 333.

36 Em oposição aos "ultraliberais" à la Mises ou mesmo ao paradoxo brasileiro de "liberais conservadores". 
No capítulo sobre o mérito e a herança, parece-me, não é dito nada. Isso pode ter uma relação com o fato de Piketty, sem falar do capitalismo como um "horizonte não ultrapassável”, à François Furet, o toma como um sistema econômico e social do qual jamais a humanidade possa sair. Não há verdadeiramente um "outro mundo possível" para retomar o termo do ATTAC e do altermundialismo. Esse sistema não é exatamente uma constante, pois é marcado por "uma dinâmica da repartição de riquezas que coloca em jogo poderosos mecanismos alternativamente no sentido da convergência e da divergência", mas esta dinâmica não caminha na direção de sua superação ${ }^{37}$.

E os mesmos Marques e Leite apontam:

Os séculos abrangidos pelas estimativas de Piketty contemplam vários modos de produção, começando na Antiguidade e terminando no capitalismo. Mas talvez uma das noções que faltem a Piketty seja o de modo de produção e, por isso, Ihe pareça "normal" comparar realidades que não podem ser objeto de comparação. Se modo de produção se define como um modo particular de os homens se organizarem e distribuírem a produção, o que pressupõe determinado grau de desenvolvimento das forças produtivas e o estabelecimento de relações de produção particulares que envolvem as classes sociais existentes, não é possível "olhar" o passado a partir de categorias que surgiram e vigoram em outro tempo histórico ${ }^{38}$.

37 CHESNAIS, François. Réflexions sur "Le capital au XXle siècle" de Thomas Piketty. ATTAC, Acessivel em https://france.attac.org/nos-publications/les-possibles/numero-1-automne-2013/ debats/article/reflexions-sur-le-capital-au-xxie-1312. Apud: MARQUES, Rosa Maria; LEITE, Marcel Guedes. Notas críticas sobre O Capital no século XXI de Thomas Piketty. Revista de Economia Política, vol. 36, no 4 (145), pp. 684-703, outubro dezembro/2016. p. 13.

38 MARQUES, Rosa Maria; LEITE, Marcel Guedes. Notas críticas sobre O Capital no século XXI de Thomas Piketty. Revista de Economia Política, vol. 36, $n^{\circ} 4$ (145), pp. 684-703, outubro dezembro/2016. p. 12. 
E isso é assim porque Piketty adotou - deliberadamente - o ponto de vista burguês na sua pesquisa. Isso ele mesmo o diz: "Que fique claro: minha proposta aqui não é defender os trabalhadores em qualquer desavença com seus patrões, mas ajudar todos a ter uma visão clara da realidade" ${ }^{\prime \prime}$. A visão "clara" da realidade é do observador desinteressado, neutro. Ocorre que em situação de injustiça manifesta ${ }^{40}$, não tomar o posicionamento (a defesa) da parte injustiçada não é ter visão clara da realidade, pois é ignorar no concreto da pesquisa o que a realidade é: injusta. Piketty toma o capitalismo como totalidade divina, insuperável, inquestionável, a qual todos, mesmo a massa de explorados, devem se resignar a viver sob o jugo. Piketty não reconhece exterioridade ao capital e por isso é incapaz de criticá-lo radicalmente, assim que não admira que as políticas que ele sugere que sejam adotadas contra a desigualdade (no nível para ele "insustentável", uma vez que admite um certo nível de desigualdade) sejam meramente reformistas (ainda que estrategicamente desejáveis na luta anticapitalista).

\footnotetext{
39 PIKETTY, Thomas. O capital no século XXI. Trad. Monica Baumgarten de Bolle. Rio de Janeiro: Intrínseca, 2014. p. 46.

40 Da qual Piketty tem consciência: "No plano simbólico, a desigualdade entre capital e trabalho é extremamente violenta. Ela bate de frente com as concepções mais comuns do que é justo e do que não é, e, portanto, não surpreende que o assunto às vezes acabe deflagrando agressões físicas. Para todos aqueles que nada possuem além de sua força de trabalho e que, frequentemente, vivem em condições modestas, para não dizer miseráveis, como no caso dos camponeses do século XVIII ou dos mineiros de Marikana, é difícil aceitar que os detentores do capital - alguns dos quais, ao menos em parte, herdam essa condição - possam se apropriar de um montante significativo da riqueza produzida sem que tenham trabalhado para isso. A participação do capital pode alcançar níveis elevados: geralmente entre um quarto e a metade de todo o valor produzido. Contudo, às vezes ela chega a superar essa parcela nos setores que o utilizam de maneira mais intensiva, como a mineração. Quando há monopólios locais, a participação pode ser ainda maior". PIKETTY, Thomas. O capital no século XXI. Trad. Monica Baumgarten de Bolle. Rio de Janeiro: Intrínseca, 2014. p. 46 - nota-se que, para o nosso economista, a desigualdade entre capital e trabalho pode deflagrar em agressões físicas devido à sua violência no "plano simbólico", por causa de concepções divergentes do que seja justo, e não devido à violência [primeira] da miséria que ele mesmo atesta haver. A questão para ele é defender [fazer convencer à classe trabalhadora] que é justo essa transferência de valor do trabalho produzido pelos trabalhadores para as mãos da classe capitalista que não trabalha, mas que a mesma se mantenha em níveis "razoáveis" (de roubo manifesto).
} 


\section{VI}

Sigmund Freud fala-nos do "mal-estar na cultura". Ora, considerando, pois, que a esfera cultual diz respeito à totalidade da vida humana (a vida humana é uma vida cultual inevitavelmente), então o mal-estar na cultura é, arqueologicamente, um mal-estar no culto. A traição que o ser humano experimenta na sociedade em que vive se refere à degeneração da sua vida religiosa. Ao invés de prestar culto (com os frutos do seu trabalho), a pessoa é o "produto" (a mercadoria) apresentado no culto como oferecimento de sacrifício no altar do mercado capitalista. O ser humano não tem, propriamente, vida religiosa, mas é a matéria oferecida em sacrifício no ofício religioso - não é o sujeito neste ofício, é o bode. Freud intuiu a relação ao iniciar $O$ mal-estar na cultura com uma consideração religiosa e ao terminar (ainda que de passagem) com uma consideração econômica ${ }^{41}$. Faltou-lhe, sem dúvida, e como ele mesmo confessa, a coragem de se erguer como profeta entre seus irmãos ${ }^{42}$. Coragem que não faltou àqueles que se opuseram contra o culto fetichista no reino de Israel ao declararem: "Basta de trazer-me oferendas vãs: elas são para mim incenso abominável (...). Cessai de praticar o mal, aprendei a fazer o bem! Buscai o direito, corrigi o opressor! Fazei justiça a órfão, defendei a causa da viúva!"43 - o profetismo israelita sempre foi uma questão político-econômica, de libertação político-econômica. Assim que é um erro o discurso antirreligioso que ainda se faz presente em muitos setores progressistas de uma certa intelectualidade que se tem por "esclarecida" e "desconstruída", na intenção de combater a "ideologia" de que a religião

\footnotetext{
${ }^{41}$ "Penso que a ética pregará em vão enquanto a virtude não for recompensada já na Terra. Também me parece fora de dúvida que uma mudança real nas relações do homem com a propriedade seria de mais ajuda que qualquer mandamento ético". FREUD, Sigmund. O mal-estar na cultura. Trad. Renato Zwick. Porto Alegre: L\&PM Editores, 2010. p. 182.

42 "Assim, perco o ânimo de me fazer profeta entre meus semelhantes, e me curvo à censura que me fazem de que não sei lhes trazer nenhum consolo (...)". FREUD, Sigmund. O mal-estar na cultura. Trad. Renato Zwick. Porto Alegre: L\&PM Editores, 2010. p. 182.

43 Isaías 1, 13.17.
} 
seria necessariamente expressão. Não são poucos os que consideram a religião a ideologia par excellence. No entanto, não é o altar que deve ser destruído, é o culto fetichista que deve sê-lo. Culto fetichista que os "ateus" sob o stalinismo exerceram em nome do "devir necessário do comunismo" da qual se tinham por sacerdotes. O encobrimento ideológico [caso queira ter algum conteúdo] é a inversão fetichista - uma ideologia é ideologia justamente porque inverte a relação das coisas.

Una vez absolutizado, idolatrizado o fetichizado el capital se le inmola al mismo trabajador, ya que se le extrae vida (al no pagársele en el salario toda la vida que objetiva en el valor del producto, el excedente como plusvalor) y es ofrecida al dios al que se refiere frecuentemente Marx: a Moloch, a Mammón, dioses fenicios de Tiro y Sidón, a quienes se le inmolan víctimas humanas en holocausto ${ }^{44}$.

O altar sempre estará aí, a diferença é se haverão sacrifícios humanos sobre ele (oferecidos a Moloch) ou se se oferecerão as primícias da terra para serem consumidas entre todos os produtores - como numa ceia onde todos saem satisfeitos por terem dado e por terem, igualmente, recebido.

\section{REFERÊNCIAS}

BENJAMIN, Walter. O capitalismo como religião. Trad. Nélio Schneider. São Paulo: Boitempo, 2013.

DUSSEL, Enrique. Ética da libertação na idade da globalização e da exclusão. Trad. Ephraim Ferreira Alves, Jaime A. Classen, Lúcia M. E. Orth. Petrópolis: Editora Vozes, 2000. https://doi.org/10.18542/rmi.vii2.2894

DUSSEL, Enrique. Pablo de Tarso em la filosofia politica actual. Ciudad de México: San Pablo, 2012.

44 DUSSEL, Enrique. 16 tesis de economia política: interpretación filosófica. México: Siglo XXI Editores, 2014. p. 117 [§7.16]. 
DUSSEL, Enrique. Para uma ética da libertação latino-americana V: uma filosofia da religião antifetichista. Trad. Luiz João Gaio. São Paulo: Edições Loyola; Editora UNIMEP: Piracicaba, s/a. https://doi.org/10.5380/rfdufpr.v27io.9166 DUSSEL, Enrique. 16 tesis de economia política: interpretación filosófica. México: Siglo XXI Editores, 2014.

FREUD. Sigmund. O mal-estar na cultura. Trad. Renato Zwick. Porto Alegre: L\&PM Editores, 2010.

LEVINAS, Emmanuel. Totalidade e infinito. Trad. José Pinto Ribeiro. Lisboa: Edições 70, 2000.

MARQUES, Rosa Maria; LEITE, Marcel Guedes. Notas críticas sobre “O Capital no século XXI" de Thomas Piketty. Revista de Economia Política, v. 36, n. 4 (145), p. 684-703, out./dez. 2016. https://doi.org/10.1590/0101-31572016v36no4a02 MARX, Karl. El capital, tomo III. Trad. León Mames. México: Siglo XXI, 1976. PIKETTY, Thomas. O capital no século XXI. Trad. Monica Baumgarten de Bolle. Rio de Janeiro: Intrínseca, 2014.

PROUDHON, Pierre-Joseph. Sistema das contradições econômicas, ou, Filosofia da miséria, tomo I. Trad. J. C. Morel. São Paulo: Ícone, 2003.

ROMEY, Kristin. Ancient Mass Child Sacrifice May Be World's Largest. In: National Geographic, april 26, 2018. Disponível em: https://news.nationalgeographic.com/2018/04/mass-child-human-animal-sacrifice-peru-chimu-science/. Acesso em: 27 maio 2019. 19h.

\section{ENDEREÇO CORRESPONDÊNCIA:}

Av. Ipiranga, 6681 - Partenon, Porto Alegre - RS, 90619-900 